Research Article

Open Access

Anda Kauliṇa*, Daina Voita, Irēna Trubina, Toms Voits

\title{
Children with Special Educational Needs and Their Inclusion in the Educational System: Pedagogical and Psychological Aspects
}

DOI 10.1515/sigtem-2016-0015

\begin{abstract}
One of the measures of the quality of education system is equal access to the education opportunity to enable learning for everyone. In the recent years, multiple conventions, declarations, announcements and resolutions regarding inclusive education have been approved internationally and included in the Latvian law of education. Nevertheless, even with the abundant amount of data and previous research results, the introduction and provision of inclusive education in practice has been controversial. The main focus has been placed on child inclusion within the educational system, but support for teachers and parents or legal guardians has not always been sufficient. For inclusive education to be truly successful, all involved parties should be receiving adequate support. Aim of the present study: analysis and evaluation of the present state of inclusive education framework and its success within the Latvian educational system. Materials and methods: literature review, survey. Conclusions: Inclusion of children with special educational needs in the inclusive education framework is a complicated pedagogical and psychological process requiring a specific attitude and preparedness of the education professionals, school staff, parents, children and society as a whole.
\end{abstract}

Keywords: children, special educational needs, inclusive education.

\section{Introduction}

The main principle of inclusive education is to provide qualitative education available and accessible to everyone, disregarding one's needs and abilities, social status, race, ethnicity, nationality, gender, religion, political views and health condition, in an encouraging and supportive environment. The main aim of inclusive education is to reduce social barriers and eliminate discrimination.

According to the Salamanca Statement of 1994 (UNESCO, 1994), inclusive education is based on the principles of social justice and provides everyone with equal access to education. European Agency for Special Needs and Inclusive Education (2009) has developed principles for promotion of quality in inclusive education, where one of the core tenets is the thesis that inclusive education creates grounds to guarantee equal opportunities for students with different kinds of special needs in all aspects of their lives (education, professional training, employment and social life). The aim of inclusive education is to avoid the exclusion of the child from the general education system based on race, ethnicity, social status, religion, gender or ability (Ainscow, 2005).

Latvian State Law states that each child, including children with reading disorders, is entitled to education and essential support measures according to their abilities (MK Noteikumi par valsts pārbaudijumu

\footnotetext{
*Corresponding author: Anda Kauliṇa: Riga Teacher Training and Educational Management Academy, Latvia, E-mail: anda. kaulina@rpiva.lv

Daina Voita, Irēna Trubina, Toms Voits, RTTEMA, Latvia
}

(c) Br.Nc.ND ( $\odot 2016$ Anda Kaulina et al., published by De Gruyter Open.

This work is licensed under the Creative Commons Attribution-NonCommercial-NoDerivs 3.0 License. 
norises kārtību Nr. 334, 2010; MK Noteikumi par centralizēto eksāmenu saturu un norises kārtību Nr. 335, 2010). Latvian Law for the Protection of Child Rights defines a child with special needs as "a child that requires additional medical, educational or social support due to disorders caused by illness, trauma or hereditary disease, regardless of whether the child has been defined as disabled in accordance with the procedure defined by the law" (LR Bērnu tiesību aizsardzības likums. VIII nodaļa, 53. pants, 2016.). Unfortunately, due to inaccurate or delayed identification or, in some cases, no diagnostics at all, in combination with other psychosocial reasons, children with special educational needs (SEN) do not always receive regular high-quality support.

During the recent years, the number of SEN children has increased significantly: from 10,865 in the academic year 2013/2014 to 11,366 in the academic year 2014/2015. A positive trend is that the number of SEN children enrolled in mainstream schools is also steadily growing - from 2891 in academic year 2012/2013 to 3800 in academic year 2014/2015 (Izglìtības un zinātnes ministrija, 2015). However, although this is a very positive trend, the question regarding the quality of the inclusion process still persists.

\section{Aim of the Study}

To analyse and evaluate the present state of inclusive education and success of implementing it within the Latvian educational system.

\section{Material and Methods}

The present study employs literature analysis regarding inclusive education and its implementation in Latvia and elsewhere across the world. The material was gathered by means of an extensive search in Google Scholar and ScienceDirect using keywords 'inclusive education', 'special educational needs, children', etc. Research articles in English are largely focused on the inclusive education experience from the Englishspeaking world - the current situation and problems is largely reviewed in such countries as the United States of America, the United Kingdom and Australia. It would be advisable to continue research and review articles from continental Europe as well as elsewhere in the world.

\section{Results}

All children have equal rights to be included in the general education, to learn and study together - this is the core guideline of inclusive education. However, this inclusion does not always give a positive result (Lindsay, 2007). The issue is highly debatable because the process of inclusive education invokes the question of teacher and educator preparedness, parental participation and society support (Ferri, Connor, 2005).

Employing professionals to lead seminars and educate about the importance of inclusive education is not enough to create and maintain a truly inclusive culture in our schools. All involved parties - teachers, school staff, parents, children - should be involved in creating this culture and implementation of easy access to support and help, if needed (Carrington, 1999).

The goal of inclusive education is to solve a truly global problem - to ease the access to education, promote the participation of each and every learner, especially those in the risk of being excluded, and give them the opportunity to develop their skills, thus lessening the risk of social discrimination. The reason for implementation of an inclusive education system is also based on research results. Pupils with mental difficulties do not perform as well as their healthy counterparts in mainstream schools. However, when comparing the results of pupils with mental difficulties attending mainstream schools with the results of pupils with mental difficulties attending special schools, the former group displays higher academic achievement and better social competence (Freeman, Alkin, 2000; Evans, Lunt, 2002; Rogers, 2007). 
Ainscow (2005) believes that many of the obstacles in the way of implementation of inclusive education are stemming from the current way of thought. It is important to significantly change the way of thinking to open the unused potential of the current general educational system.

In order to improve the quality of inclusive education, it is important to understand that:

1. inclusion applies to all learners who have a risk of being excluded from the study process, not only those with special educational needs,

2. inclusion applies to all learners who are enrolled in a given school,

3. every child is special,

4. parental involvement and participation is an important factor in the organisation of the study process,

5. parent and teacher attitude towards inclusive education depends on their personal experience and

6. positive attitude helps with the learning of study material (Murloy, 1997).

Based on numerous years of hands-on experience, Terzi (2005) believes that it is necessary to develop individual special education programmes depending on the disability. The idea is that, in order to provide the most efficient education, one needs to understand that children are individually quite different and may need a personalised approach within the study process.

From the point of view of philosophy of education, Danforth and Rhodes (1997) gravely criticise the term 'children with special educational needs'. These authors believe that the whole field of inclusive education should be less concerned with inclusion methods and focus more on the development of such educational system where non-participation in the study process is impossible. The division of all learners in 'healthy children' and 'children with special educational needs' is a social construct that is simply unacceptable in schools and they offer deconstruction of this concept as one of the basic principles of inclusive education.

Ferri and Connor (2005) also agree with this point of view and liken the division of children by disability to racism - they introduce the term 'ableism' to describe the discrimination against one's supposed 'abilities'.

Previous studies have produced dubious results regarding the efficiency of inclusive education. Rogers (2007) studied the experiences of British parents in cases when their SEN children have been unable to keep up with the study pace in general schools. Rogers did in-depth qualitative interviews with parents whose children have at least one of the following disorders: autism, Asperger's syndrome, attention deficit and hyperactivity disorder (ADHD), learning disorders, reading and/or writing disorders, language disorders, emotional and/or behavioural disorders.

Given that inclusive education model has been made compulsory in England and Wales, all children have to learn together following a unified educational standard. However, research has shown that 'inclusion' is often only a formality and, in practice, the structured testing system and the prevalent exam culture does not allow for an individual approach to each child. Therefore, Rogers (2007) is correct in asking the question whether all children can successfully study in mainstream schools. Interviews reveal that although parents would like their SEN children to attend mainstream schools, the school management tends to be indifferent and, in some cases, even prejudicial against SEN children. It shows that within the framework of 'inclusive' education a child can find herself or himself to be lonely, isolated and abandoned, while not being able to cope with the study process and not receiving the necessary support.

Discriminatory attitude has been reported in the USA as well (Ferguson, 2008). A truly inclusive education is the goal that educators worked on since the 1980s and still one can easily observe inequality in the US educational system. White students, students with no mental disabilities and students from higher-income backgrounds are statistically significantly more likely to achieve better study results than their minority or lower income counterparts as well as children with mental disorders.

SEN children can be isolated on multiple levels within the framework of inclusive education:

- Practically - when individual work is conducted with the child, physically separating them from the rest of class;

- Intellectually - often children with special needs may find it difficult to follow the learning pace of other pupils and the curriculum;

- Emotionally - when a child gets socially isolated among their peers and is unable to form social bonds and friendships with them. 
Evans and Lunt (2002) carried out surveys and discussions within a focus group. The results show that there are multiple groups of disability that are easier or more difficult to include in the mainstream schools:

The following are easy to include:

- Children with physical difficulties;

- Children with sensory difficulties;

- Children with speech and language difficulties;

- Children with moderate or general learning difficulties;

- Children with specific learning difficulties.

The following are difficult to include:

- Children with emotional and behavioural difficulties;

- Low-incidence special education needs children needing high levels of expertise;

- Children with severe learning difficulties;

- Children with autism;

- Children needing health service input.

Thus, the question on how to provide adequate education for all children is still open (Rogers, 2007). Evans and Lunt (2002) believe that although, in theory, inclusion of all children in a unified educational system is the best possible outcome, in practice, complete inclusion of all children is idealistic and impossible, mostly due to the lack of funding and the need to change the mainstream school culture.

A survey of student teachers regarding the inclusion of pupils with Down syndrome in mainstream schools revealed that the initial response of student teachers is mostly dismissive and negative. Prior to undertaking pedagogical practice, students thought that these students may disrupt the working rhythm, they will require much more time and attention and there will not be enough support and resources available to successfully include these students in the classroom. However, following the completion of pedagogical practice, the attitudes of student teachers had changed. Their opinions were more positive towards both Down's syndrome sufferers and disability in general (Campbell, Gilmore, Cuskelly, 2003). This proves that information and education plays a crucial role in the education of young teachers and it is essential that children with special educational needs are part of the curriculum to better understand disability and its role in education. It is the combination of knowledge and experience that shape and change attitudes towards this issue as a whole.

Studies in South East England by Avramidis, Bayliss \& Burden (2000) have revealed that teachers with experience of inclusive education programmes are more open and with a more positive attitude towards children with special educational needs and their inclusion in mainstream classrooms. Teachers with relatively higher level of education also display more open attitudes. The survey results reveal that the biggest concerns are about the students with emotional and behavioural issues and their inclusion in the mainstream classroom. Although two-thirds of the teachers surveyed between 1958 and 1995 support integration and the concept of inclusive education, only one-third or less considered themselves to be have the required skills, knowledge and education to introduce inclusive education programmes. No other demographic variables (age) was found to have a statistically significant effect on teacher opinions on inclusive education (Avramidis, Bayliss, Burden, 2000).

One of the key factors that interferes with the inclusion of children with special educational needs is the teacher's unpreparedness for this job. Teachers and school staff attitudes also tend to interfere with the inclusion of SEN children in mainstream education. Matthews (2009) describes another problem with inclusive education. School staff are worried about the possibility of including children with 'hidden' disorders or difficulties. Sometimes teachers are not aware that a certain student needs additional attention and support during the study and examination process. One of the key factors here is the balance between confidentiality and privacy. One of the main reasons why pupils and their parents are unwilling to discuss their issues and difficulties is the fact that they do not want to receive any special treatment, are worried about their future prospects and career opportunities. A significant factor is the overall attitude towards 
people with special needs as lesser members of the society (Matthews, 2009).

Work with SEN children demands a clear cooperation between education professionals working in the school or educational institution. Murloy (1997) believes that it is important to form an interdisciplinary group of professionals who can cooperate across multiple areas. Common work and planning as well can result in a good support for the child in education, that, in turn, may result in better study quality and overall quality of life.

Support involves multiple components:

1. understanding, positive emotional support and encouragement,

2. information about child's options,

3. change of circumstances, collaboration and positive environment,

4. acceptance of child, active involvement in the collaborative process (Eberwein, Knauer, 2009; Ehmann, 1995).

To uncover the current atmosphere surrounding the implementation of inclusive education in Latvia, we surveyed teachers regarding their views and opinions on inclusion of SEN children in mainstream education in Latvia. The survey was anonymous. A total of 32 teachers working in mainstream schools and 30 teachers working in special schools participated in the survey. The mean length of reported work experience was 26 years, and $82 \%$ of the participants had a Master's degree in pedagogy.

Of the survey population, $32 \%$ of teachers working in mainstream schools reported that they have been working with SEN children, but they felt that their professional expertise was not sufficient to successfully work in the inclusive education framework. $17 \%$ of the participants rated their professional competence as low. Teachers working in special schools report lack of competence as well - $9 \%$ of this subgroup also admit lacking the necessary skills and knowledge. In sum, $81 \%$ of the surveyed teachers self-report mediocre capabilities to prepare an individual study plan for SEN children.

Surveyed teachers admit that when including SEN child in the mainstream classroom, it is important to evaluate the severity of disorder or disability and the fit of the chosen education programme to the individual child. This particularly resonates with primary school teachers, who admit that SEN children cannot always be successfully included in the mainstream classroom.

Teachers believe that additional financial support is essential to ensure successful implementation of inclusive education in Latvia. Alongside that, support from the general public, more information, knowledge and skills are needed. In order to improve the quality of inclusive education in Latvia, it is necessary to further develop the education of future teachers, raise wages of those teachers working with SEN children and change the overall attitude of the general public towards people with special needs.

In conclusion, work with SEN children requires specific knowledge, skills and pedagogical abilities. Support and compensatory measures, development and use of a support system needs to be based on a well-designed diagnostic process involving relevant professionals and parents. In order for teachers to successfully work within the inclusive education framework, there needs to be a change in the attitudes and values as well as proper teacher education providing good competencies, skills and knowledge.

\section{Conclusions}

Although inclusive education is becoming more and more widely adopted worldwide, there are still questions regarding the correct methods to implement it. Work has been done in the Latvian educational system to enable as many children as possible to be included in the mainstream schools, disregarding their abilities; however, there is a lack of data regarding the success of inclusive education in Latvia. Previous literature shows that a significant aspect of inclusive education is the teacher knowledge and understanding of an efficient work, suitable professional skills, pedagogical and psychological competencies and personality traits.

Involvement of society and cooperation with the families of SEN children lessens the discriminatory attitudes. Future research should cover the experiences of inclusive education from the point of view of SEN children, their parents and teachers. 


\section{References}

Ainscow, Mel (2005) Developing Inclusive Education Systems: What are the levers for change? Journal of Educational Change 6: 109-124.

Avramidis, Elias, Bayliss, Phil \& Burden, Robert (2000) A Survey into Mainstream Teachers' Attitudes Towards the Inclusion of Children with Special Educational Needs in the Ordinary School in one Local Education Authority. Educational Psychology 20:2, 191-211.

Campbell, Jennifer, Gilmore, Linda and Cuskelly, Monica (2003) Changing student teachers' attitudes towards disability and inclusion. Journal of Intellectual \& Developmental Disability 28(4): 369-379.

Carrington, Suzanne (1999) Inclusion needs a different school culture. International Journal of Inclusive Education 3(3):257-268.

Connor, David J. \& Ferri, Beth A. (2007) The conflict within: resistance to inclusion and other paradoxes in special education. Disability \& Society 22:1, 63-77.

Danforth, Scot and Rhodes, William C (1997) Deconstructing Disability: A Philosophy for Inclusion. Remedial and Special Education 18(6): 357-366.

Eberwein, H., \& Knauer, S. (Hrsg.) (2009). Handbuch Integrationspädagogik. (7. Auflage). Weinheim, Basel: Beltz Verlag, S. 554.

Ehmann, H. (1995). Ist mein Kind Legastheniker? Ein Ratgeber zur Lese- und Rechtschreibschwäche. München: Beck, S. 140.

Evans, Jennifer \& Lunt, Ingrid (2002) Inclusive education: are there limits? European Journal of Special Needs Education, 17:1, 1-14.

Ferguson, Dianne L. (2008) International trends in inclusive education: the continuing challenge to teach each one and everyone, European Journal of Special Needs Education, 23:2, 109-120.

Ferri, Beth A and Connor, David J (2005) Tools of Exclusion: Race, Disability, and (Re)segregated Education. Teachers College Record 107(3): 453-474.

Freeman, Stephanny F. N. \& Alkin, Marvin C. (2000) Academic and Social Attainments of Children with Mental Retardation in General Education and Special Education Settings. Remedial and Special Education 21:1, 3-26.

Izglītības un zinātnes ministrija (2015). Darba sesija “lekḷaujoša izglīīība mūsdienīga skolā” available online at http://www. izm.gov.lv/images/aktualitates/izglitiba_krustceles/leklaujosa-izglitiba_200815_IZM.pdf [Accessed 18.02.2016].

Lindsay, Geoff (2007) Annual review: Educational psychology and the effectiveness of incluysive education/mainstreaming. British Journal of Educational Psychology 77: 1-24.

Matthews, Nicole (2009) Teaching the 'invisible' disabled students in the classroom: disclosure, inclusion and the social model of disability. Teaching in Higher Education, 14:3, 229-239.

Murloy, E. S. (1997). Building a neighborhood network: Interorganizational collaboration to prevent child abouse and neglect. Social Work, 42 (3), 255-264.

Noteikumi par centralizēto eksāmenu saturu un norises kārtību. MK Noteikumi Nr. 335. LR MK, 2010. http://www.izm.izm.gov. Iv/normativie-akti/politikas-planosana/1016.html (skatīts:14.02.2016.).

Noteikumi par valsts pārbaudījumu norises kārtību. MK Noteikumi Nr. 334. LR MK, 2010. http://www.izm.izm.gov.lv/ normativie-akti/politikas-planosana/1016.html (skatīts:14.02.2016.).

Rogers, Chrissie (2007) Experiencing an 'inclusive' education: parents and their children with 'special educational needs', British Journal of Sociology of Education, 28:1, 55-68.

Soriano, V., Grünberger, A. and Kyriazopoulou, M. (eds.) 2009. Multicultural Diversity and Special Needs Education, Odense: European Agency for Development in Special Needs Education.

Terzi, Lorella (2005) Beyond the Dilemma of Difference: The Capability Approach to Disability and Special Educational Needs. Journal of Philosophy of Education 39(3): 443-459.

UNESCO (1994) The Salamanca Statement and Framework for Action on Special Needs Education. Available online at http:// unesdoc.unesco.org/images/0009/000984/098427eo.pdf [accessed 20.02.2016

The preparation of this paper has been supported by the EEA and Norway Grants 2009-2014 programme LV05 "Research and Scholarship Programme” Project Nr.: NFI/R/2014/070 "Health and Social Indicators of Participation in Physical Activities for Children with Disabilities” 